\title{
Efficiency of ECE Applied on RC Slab using Locally Available Un-Galvanized Steel with Conductive Cement Paste Anode
}

\author{
Nourhan EL-sayed, Mohamed Kohail, Mohamed A. Khalaf
}

\begin{abstract}
Electro-chemical Chloride Extraction (ECE) is considered one of the most effective technique used to extract chloride ions from reinforced concrete structures. Effectiveness of using ECE depends on some important factors such as anode type, current intensity, extraction duration, type of rebar and chemical properties of concrete. On the other hand, ECE may cause some detrimental effects on some mechanical properties of concrete and steel such as a reduction in bond and compressive strengths of concrete, and embrittlement (i.e. reduction in ductility) ductility of reinforcing steel.

The major aim of this research work was to investigate the effectiveness of ECE using locally available un-galvanized steel mesh with conductive cement paste anode as a new type of anode on a reinforced concrete slab as a structural element. The slab behavior before and after ECE was studied by determining compressive strength, water absorption rate, concrete chloride content and steel corrosion potential. The slab behavior was studied taken into consideration the established steel arrangement with spacing $20 \mathrm{~cm}$ between re-bars. Another aim of this research work was to investigate the effect of initial chloride content on chloride extraction efficiency by applying optimum current intensity and duration (3 A/m $\mathrm{m}^{2}$ and 6 weeks) on cylinders with pure chloride content $0.4 \%$ and $0.8 \%$ (by weight of cement). Effectiveness of ECE with small initial chloride content $0.4 \%$ and $0.8 \%$ was compared with that of high initial chloride content (2.5\%) in order to know if the initial chloride content is an important factor on ECE effectiveness or not.
\end{abstract}

Keywords: ECE, un-galvanized steel anode, conductive cement paste, corrosion.

\section{INTRODUCTION}

Corrosion is one of the most serious problems which has a bad effect on reinforced concrete properties [1], [2]. Carbonation is considered one of the main important causes of corrosion which causes neutralization of all alkaline ingredients in cement due to a remarkable drop in $\mathrm{PH}$ value [3]. This drop will cause extensive widespread corrosion of reinforcing steel

Revised Manuscript Received on April 25, 2020.

* Correspondence Author

Nourhan EL-sayed*, Structural Engineering department, Ain Shams University, Cairo, Egypt. Email: nourhan.elsayed95@eng.asu.edu.eg

Mohamed Kohail, Structural Engineering department, Ain Shams University, Cairo, Egypt. Email: m.kohail@eng.asu.edu.eg

Mohamed Abdel Moaty Khalaf, Structural Engineering department, Ain Shams University, Cairo, Egypt. Email: Mohamed_khalaf@ eng.asu.edu.eg

(C) The Authors. Published by Blue Eyes Intelligence Engineering and Sciences Publication (BEIESP). This is an open access article under the CC BY-NC-ND license (http://creativecommons.org/licenses/by-nc-nd/4.0/)
[4] which causes a continuous degradation of reinforced concrete properties [5]-[7].Chlorides could be from several sources either internal sources or external sources. Internally; chlorides may be coming from using seawater as mixing water or by using chloride contaminated aggregates. Externally; they can diffuse in concrete from the outside environment as a result of sea salt spray and direct seawater wetting. There is a growing need to improve the durability of concrete structures [8]-[11] or to rehabilitate the damaged one [12]-[14]. So, many different methods are used to rehabilitate concrete with high percentage of chloride like electrochemical re-alkalization of concrete, electrochemical chloride removal [15]-[17], electrochemical injection of organic corrosion inhibitor [18]-[20]. There are many rehabilitation methods such as using corrosion inhibitors (e.g. calcium nitrate) [21], cathodic protection (CP) [22] and different repair methods (like repair patches to avoid bad effects of corrosion on steel rebar in reinforced concrete). Optimum current intensity and duration for ECE were determined on cylinders in previous work based on maximum chloride extraction efficiency and minimum bond strength loss. Applying them on slab and cylinders with small initial chloride content as application on ECE to determine the effectiveness of ECE.

\section{EXPERIMENTAL WORK}

\section{A. Material and test specimens}

The used materials were ordinary portland cement (CEM 1) of chemical and physical properties given in Table-I; fine aggregates (natural sand of fineness modulus 2.498, specific weight 2.67, volumetric weight $1.54 \mathrm{t} / \mathrm{cm}^{3}$ and percentage of fine materials $2.4 \%$ ) and crushed stone coarse aggregates (10 mm NMS, volumetric weight $1.55 \mathrm{t} / \mathrm{cm}^{3}$, water absorption $1.5 \%$ and 2.703 specific weight). For the first mixture, sodium chloride $(\mathrm{NaCl})$ solution (of concentration $4 \%$ by weight of cement) was added to the mixture which is equivalent to $2.5 \%$ of pure chloride dissolved in mixing water $(\mathrm{W} / \mathrm{C}=0.6)$ for the slab. The second mixture differed in admixing $0.64 \%$ of $\mathrm{NaCl}$ by weight of cement which is equivalent to $0.4 \%$ of pure chloride and the third mixture was admixed with $1.64 \%$ of $\mathrm{NaCl}$ by weight of cement which is equivalent to $0.8 \%$ of pure chloride. The reinforced concrete samples for the second and third mixture were cylinders $(200 \mathrm{~mm}$ height and $70 \mathrm{~mm}$ diameter) with a $10 \mathrm{~mm}$ diameter steel bar located at the center.

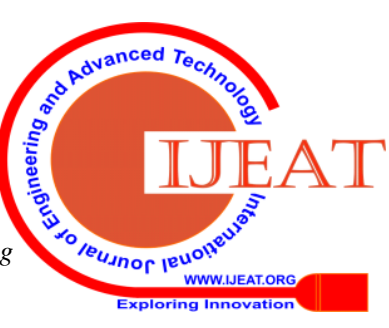


The used anode was conductive cement paste with un-galvanized steel mesh Fig. 1 cylinder of dimensions 210 $\mathrm{mm}$ height and $90 \mathrm{~mm}$ diameter. The proportion of conductive cement paste was $20 \%$ of graphite and 0.65 of water by weight of cement. Cylinder specimens were cast in
PVC molds. Slabs were cast in a wood form with dimension (60 $\mathrm{cm} \times 60 \mathrm{~cm} \times 8 \mathrm{~cm}$ ). Table-II shows the values of mix

Table-I: Shows the Physical \& Chemical properties of cement

\begin{tabular}{|c|c|c|c|c|c|c|c|c|c|}
\hline Element & $\mathrm{SiO}_{2}$ & $\mathrm{Al}_{2} \mathrm{O}_{3}$ & $\mathrm{Fe}_{2} \mathrm{O}_{3}$ & $\mathrm{Cao}$ & $\mathrm{MgO}$ & $\mathrm{SO}_{3}$ & $\mathrm{Na}_{2} \mathrm{O}$ & $\mathrm{K}_{2} \mathrm{O}$ & L.O.I* \\
\hline Cement & 20.13 & 5.32 & 3.61 & 61.63 & 2.39 & 2.87 & 0.37 & 0.13 & 1.96 \\
\hline
\end{tabular}

* loss on ignition

Table-II: Mix proportions for one cubic meter of concrete.

\begin{tabular}{|c|c|c|c|c|c|}
\hline $\begin{array}{c}\text { Cement } \\
\left(\mathrm{kg} / \mathrm{m}^{3}\right)\end{array}$ & $\begin{array}{c}\text { Aggregate } \\
\left(\mathrm{kg} / \mathrm{m}^{3}\right)\end{array}$ & $\begin{array}{c}\text { Sand } \\
\left(\mathrm{kg} / \mathrm{m}^{3}\right)\end{array}$ & $\begin{array}{c}\text { Water } \\
\left(\mathrm{kg} / \mathrm{m}^{3}\right)\end{array}$ & $\begin{array}{c}\mathrm{NaCl} \\
\left(\mathrm{kg} / \mathrm{m}^{3}\right)\end{array}$ & $\begin{array}{c}\text { Average } \mathrm{f}_{\mathrm{cu}} \\
(\mathrm{Mpa})\end{array}$ \\
\hline 350 & 1093 & 545 & 210 & 10.5 & 25 \\
\hline
\end{tabular}

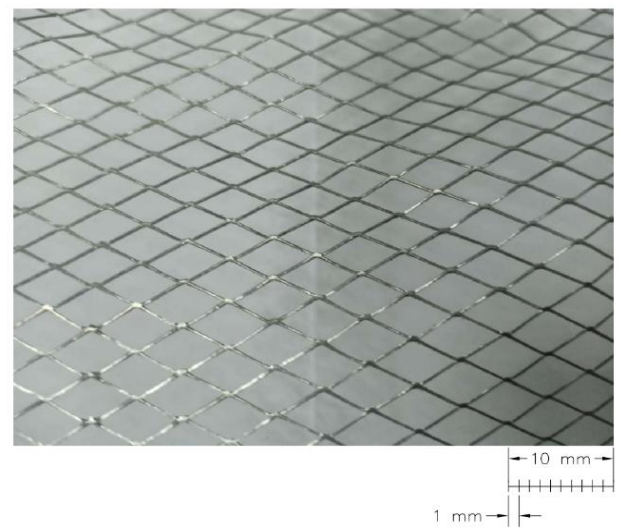

Fig. 1: Un-galvanized steel mesh used

proportions for one cubic meter of concrete. Concrete compressive strength was determined using $10 \mathrm{~cm} \mathrm{x10} \mathrm{cm}$ x10 cm cubes after 7 and 28 days as stated by ECC 203/2017 [23]. The average 28-days compressive strength of concrete was $25 \mathrm{MPa}$ (the most commonly used value in Egypt).

\section{B. Methodology}

ECE process was conducted on 12 reinforced concrete cylindrical specimens with current intensity $3 \mathrm{~A} / \mathrm{m}^{2}$ and duration 6 weeks. The current was applied using a DC power supply between the rebar (working as a cathode) and an un-galvanized steel mesh with conductive cement paste (working as an anode) [24] as shown in Fig. 2 for cylinders. The connection of ECE for slab was as shown in Fig. 3 and the schematic diagram Fig. 4. Twelve cylinders were connected (6 cylinders were prepared for the pull-out test and another six prepared for chloride content test for two mixtures). Four cylinders were disconnected by DC power supply as a reference of control chloride content and bond strength for two mixtures $0.4 \%$ and $0.8 \%$. Specimen prepared for pull-out test differed from specimen prepared for chloride content test in the length of steel rebar (40 cm for the pull out test and 25 $\mathrm{cm}$ for chloride content test). The immerged rebar length of all specimens were $17.5 \mathrm{~cm}$. Each sample was cut into three layers within a distance 10-20-30 mm from the rebar and then grinded to test them after that. Graphite powder was added to cement paste in order to overcome its low conductivity as recommended by Saraswathy [25]. A sodium hydroxide solution $(0.004 \mathrm{~g} / \mathrm{L}$ of $\mathrm{NaOH})$ electrolyte $(\mathrm{PH}=10)$ was used as recommended by Lin [26]. The electrolyte was replaced weekly to avoid saturation of solution by chloride ions extracted from concrete as recommended by Lin [26]. Two slabs were tested, the first one was control slab and the second one was connected by DC power supply.

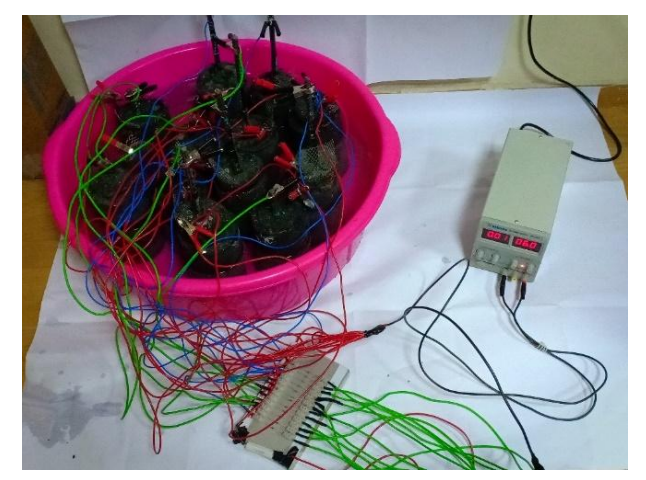

Fig. 2: Details of ECE circuit for cylinders

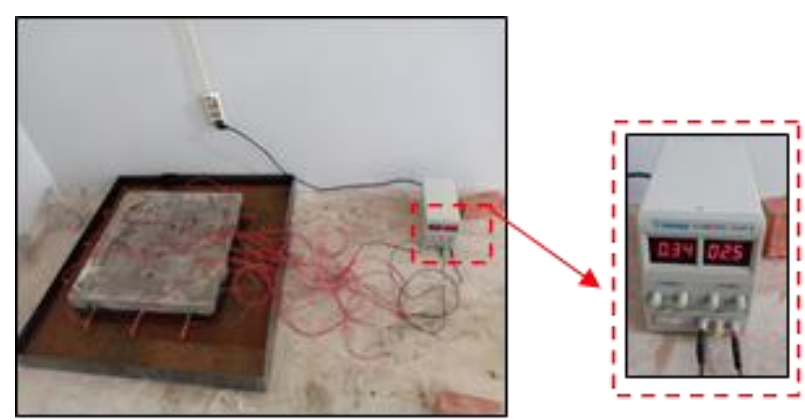

Fig. 3: Details of ECE circuit for slab

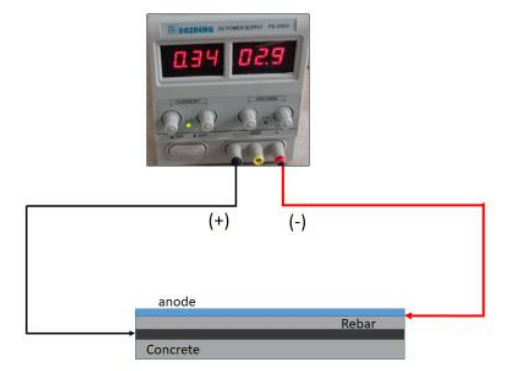

Fig. 4: Schematic diagram for slab ECE connection

\section{Drilling method}

Published By:

Blue Eyes Intelligence Engineering

\& Sciences Publication

(C) Copyright: All rights reserved.

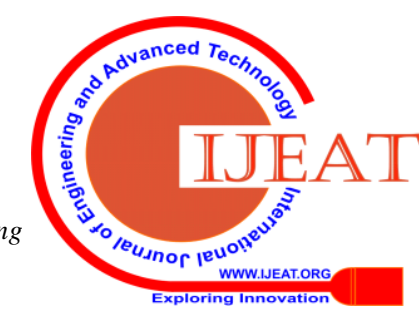


Obtaining Powder from various locations in the concrete slab and various distance of cylinders using a bench drill with a diameter of $1.6 \mathrm{~cm}$ as shown in Fig. 5 [27]. Powder of concrete was used to determine chloride concentration. Locations of drilling from the slab were as shown in Fig. 6. A, $\mathrm{B}$, and $\mathrm{D}$ located at the intersection of two rebar, $\mathrm{C}$ located over one rebar, and $\mathrm{E}$ located in the middle of two re-bars.

The chosen locations were to investigate the effectiveness of chloride extraction at different locations from the steel rebar arrangement.

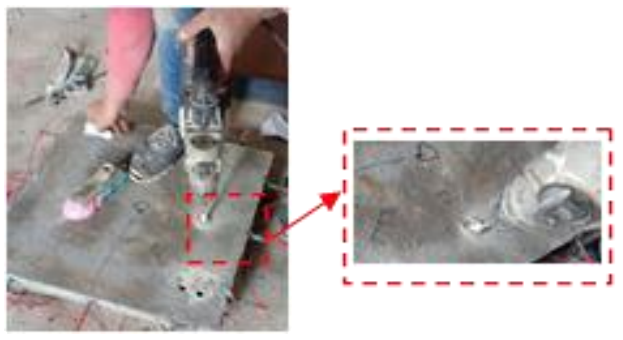

Fig. 5: Drilling method from the slab

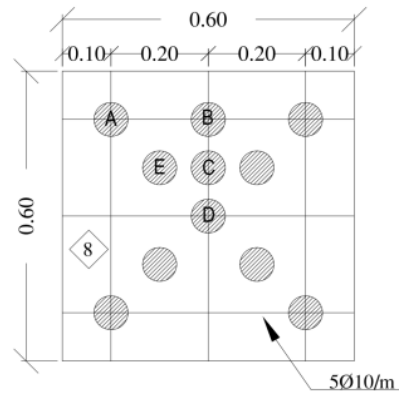

Fig. 6: Locations of drilling from the slab

\section{EXPERIMENTAL PROCEDURE}

\section{A. Chloride content test}

Chloride content $(\mathrm{P})$ was determined before and after ECE as follows:

A sample of $20 \mathrm{gm}$ from oven-dried concrete $\left(65^{\circ} \mathrm{C}\right.$ for 2 hours) was grinded and $10 \mathrm{gm}(\mathrm{G})$ powder was taken from it and added to $100 \mathrm{gm}$ distilled water $\left(\mathrm{V}_{1}\right)$ and stir it for half-hour then filtrate it. After that, a $20 \mathrm{gm}\left(\mathrm{V}_{2}\right)$ filtration was taken and 2 drops of phinopithline (PHPH) were added until pink color appeared, then drops of dilute sulfate acid were added till the pink color disappeared. Adding 10 drops of potassium chromate indicator then adding a drop by drop from silver nitrate of concentration 0.02 mole/L (C) and determining its volume $\left(\mathrm{V}_{3}\right)$. Equation (1) is used to calculate the free chloride content according to Baoguo Ma [28].

Chloride content (P) was determined before and after ECE as follows:

$$
P=\frac{C * V 3 * 0.03545}{G * \frac{V 2}{V 1}} * 100 \%
$$

\section{B. Half-Cell Potential measurement (HCP)}

HCP test shows the change of reinforcing bar from a passive to an active state. It is suggested in ASTM C-876 that, the rebar has a corrosion possibility higher than $90 \%$ when the measured HCP is higher than $-350 \mathrm{mV}$ (CSE) and a potential higher than $-500 \mathrm{mV}$ (CSE) represents severe corrosion happened on the steel. The test was conducted on the slab before and after ECE according to (Method 1999) [29].

\section{Pull-out test}

The bond strength between reinforcing steel bars and concrete was determined by pull-out test. A tension machine of capacity 30 ton was used to conduct the pull-out test using a steel frame as shown in Fig. 7.
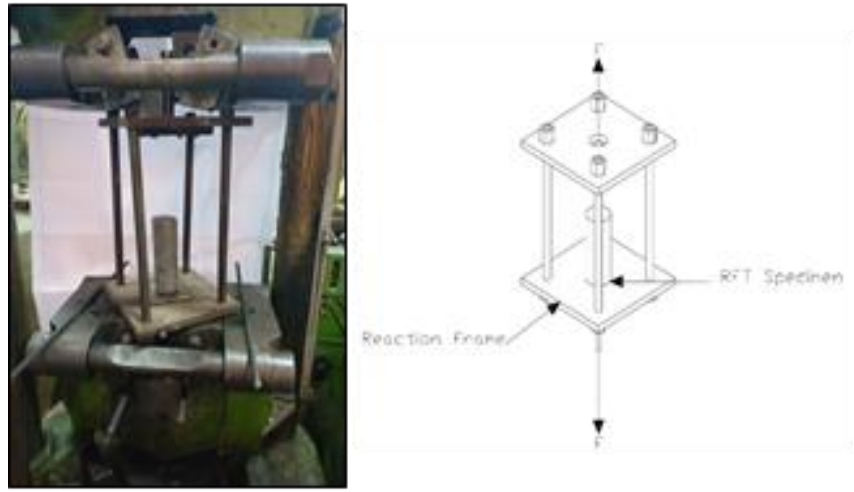

Fig. 7: Pull-out test setup

\section{Rate of water absorption test}

Two samples were prepared for the rate of water absorption test. The first concrete specimen was before ECE and the second one was after ECE. Two samples were extracted from the control slab and another sample from the slab after applying ECE for 6 weeks with current intensity $3 \mathrm{~A} / \mathrm{m} 2$ by core machine. The sample was dried into an oven until constant weight. The mass before sealing (wd) was recorded and the diameter was calculated as the average of four measurements $(100 \mathrm{~mm})$. The side surface was sealed with a plastic sheet. The mass of the sealed specimen was measured to the nearest $(0.01 \mathrm{gm})$. The supporting devices were placed, the pan was filled with tap water and the water level is 1 to 3 $\mathrm{mm}$ above the top of the supports. Start the timing device and immediately place the test surface of the specimen on the supports. The time and date of initial contact were recorded. The masses have been recorded at $60 \mathrm{sec}, 5 \mathrm{~min}, 10 \mathrm{~min}, 20$ min, $30 \mathrm{~min}, 60 \mathrm{~min}$ and every hour up to 6 hours- once a day up to three days from the start time according to ASTM C1585-13 2013 [30].

\section{E. Core test}

The main aim of this test was to determine the effect of ECE on compressive strength after applying ECE for six weeks with current intensity $3 \mathrm{~A} / \mathrm{m}^{2}$. Six specimens were extracted from the slab to conduct the test. Three specimens were extracted from the control slab before ECE and the other three specimens were extracted from the slab after applying ECE for 6 weeks with current intensity $3 \mathrm{~A} / \mathrm{m}^{2}$. Core dimensions were $6.8 \mathrm{~cm}$ diameter and $7.5 \mathrm{~cm}$ height. The test was conducted according to ECC 203/2017 [31].

\section{RESUlTS AND DISCUSSION}

\section{A. Test results for slab}

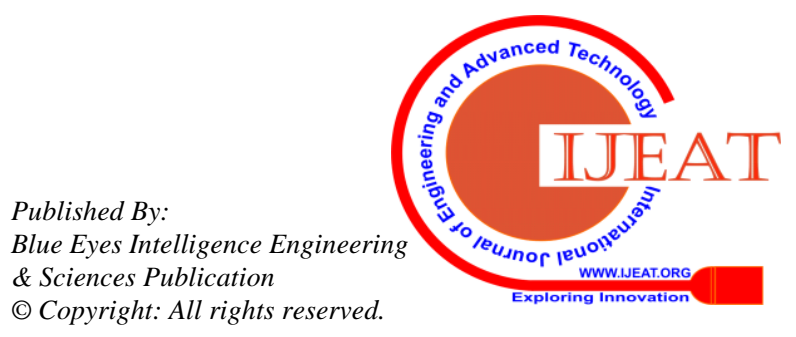


After determining optimum current intensity $3 \mathrm{~A} / \mathrm{m}^{2}$ and optimum duration 6 weeks from applying ECE on cylinders. ECE treatment was applied to a reinforced concrete slab as a structural element to know the effectiveness of the ECE on the reinforced concrete element. The reinforced steel bar arrangement effect on chloride extraction was studied by drilling powder from different locations of the slab, corrosion potential of steel re-bars, water absorption rate of concrete and compressive strength of concrete before and after ECE were studied also. The results of the tests are shown in the following:

\section{1) Chloride test results}

The chloride content of the powder obtained from different locations of the slab before and after ECE was as shown in Fig. 8. The results show that the most effective location of extraction was above the intersection of two steel bars at the corner of the slab. The lowest effective location was between steel rebar confirming that the distance between steel rebar had an effect on the efficiency of chloride extraction from the slab. This was due to the weak magnetic field in the middle between steel rebar.

The efficiency of extraction at the location A, B, C, D, and E was up to $82.08 \%, 74.35 \%, 74.56 \%, 71.25 \%$ and $31.17 \%$ respectively. The efficiency ratios showed that all locations except location $\mathrm{E}$ have almost the same efficiency due to their places near to the steel rebar as shown in Fig. 9.

\section{2) Core test results}

Results show that there was no significant loss of compressive strength of reinforced concrete before and after ECE with applying current intensity $3 \mathrm{~A} / \mathrm{m}^{2}$ for six weeks. The compressive strength of the core was $195.11 \mathrm{~kg} / \mathrm{cm}^{2}$. The difference was up to $8 \%$.

\section{3) Rate of water absorption test results}

Results show that there was no significant change in the water absorption rate before and after ECE. The rate before ECE was $0.022 \mathrm{~mm} / \mathrm{sec}^{0.5}$ and after ECE was $0.018 \mathrm{~mm} / \mathrm{sec}^{0.5}$ as shown in Fig. 10. The porosity of reinforced concrete did not change by applied ECE treatment.

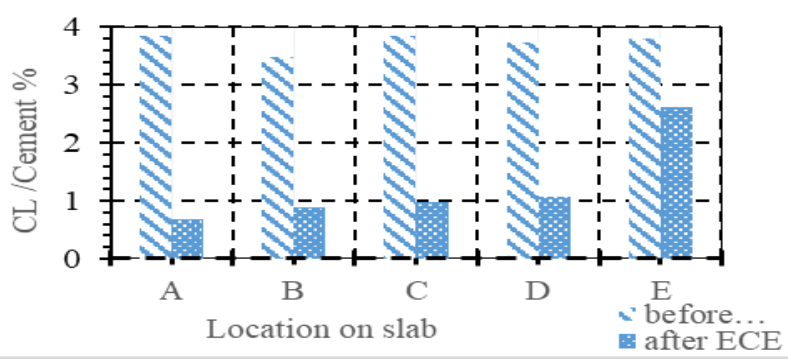

Fig. 8: Chloride content at different locations of slab before and after ECE

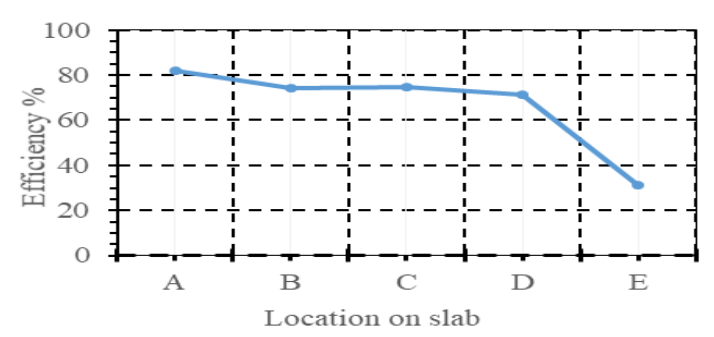

Fig. 9: Chloride extraction efficiency at different location

\section{Test results for two mixtures with chloride content}

Optimum current intensity $3 \mathrm{~A} / \mathrm{m} 2$ and optimum ECE duration 6 weeks were applied on reinforced concrete cylinders with $0.4 \%$ and $0.8 \%$ chloride content. ECE treatment was applied to these cylinders to investigate the ECE effectiveness of chloride extraction with small initial chloride content $(0.4 \%$ and $0.8 \%)$, compare this with the effectiveness of chloride extraction of initial high chloride content (2.5\%). Effectiveness of ECE with small chloride content $(0.4 \%$ and $0.8 \%)$ were compared with that of high initial chloride content (2.5\%) in order to know if the chloride content is an important factor on ECE effectiveness or not. The results of the chloride and pull-out tests which conducted on cylinders are shown in the following:

1) Test results for mixture with chloride content $(0.4 \%)$

Chloride test results showed that the effectiveness of extraction was up to $58 \%$ which differed from the efficiency of the chloride extraction when the initial chloride content was $2.5 \%$ by $17 \%$. This confirms that the high initial value of chloride content increases the efficiency of its extraction in a small percentage compared with small initial content. Chloride content before and after extraction at different distances from steel rebar was as shown in Fig. 11. Each point on graph was average of three specimens. Pull-out test showed that there was no significant loss in bond strength before and after ECE as shown in Fig. 12.

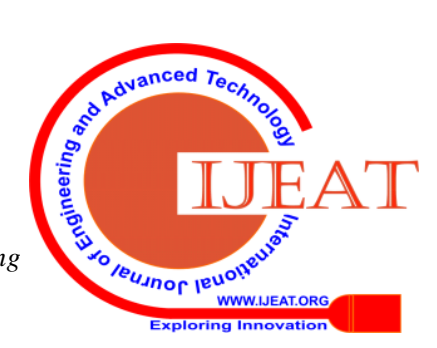




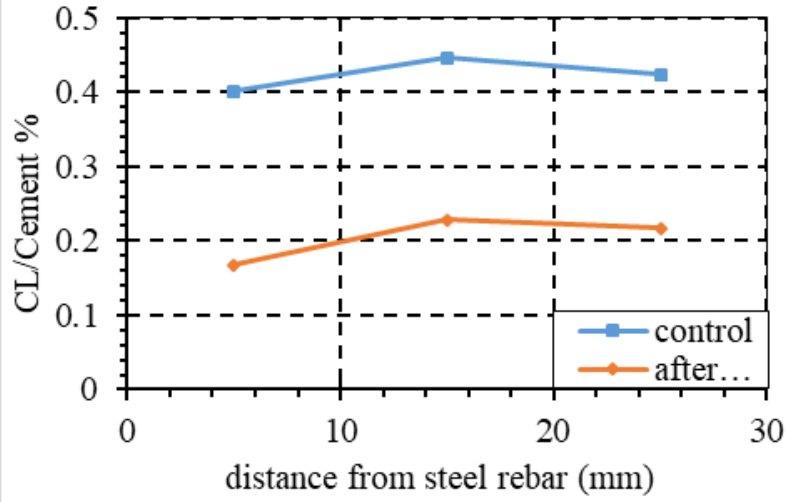

Fig. 11: Chloride content at different distances from steel bar after six weeks

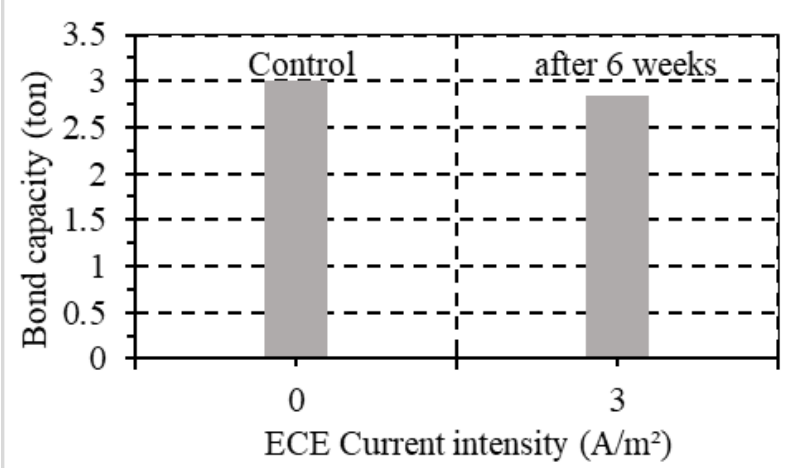

Fig. 12: Bond capacity before and after ECE

2) Test results for mixture with chloride content $\mathbf{( 0 . 8 \% )}$

Chloride test results showed that the effectiveness of extraction was up to $62 \%$ which differed from the efficiency of the chloride extraction when the initial chloride content was $2.5 \%$ by $13 \%$. It differed by about $4 \%$ from a mixture of chloride content $(0.8 \%)$. This confirms that the high initial value of chloride content increases the efficiency of its extraction in a small percentage compared with small initial content. Chloride content before and after extraction at different distances from steel rebar were shown in Fig. 13. Pull-out test showed that there was no significant loss in bond strength before and after ECE as shown in Fig. 14. The efficiency of chloride extraction in mixture with (2.5\%) pure chloride was as shown in Fig. 15.

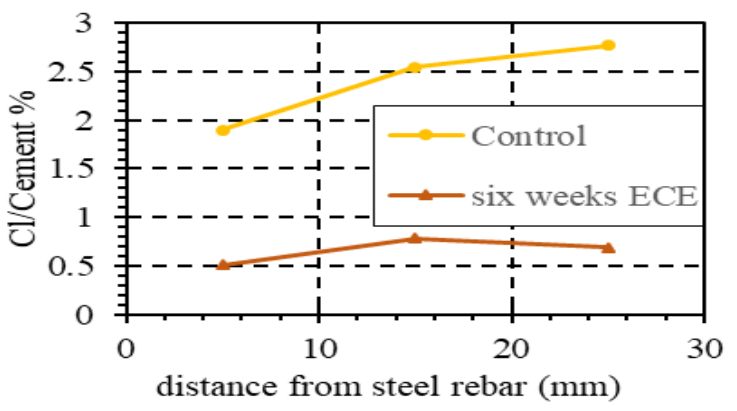

Fig. 13: Chloride content at different distances from steel bar after six weeks

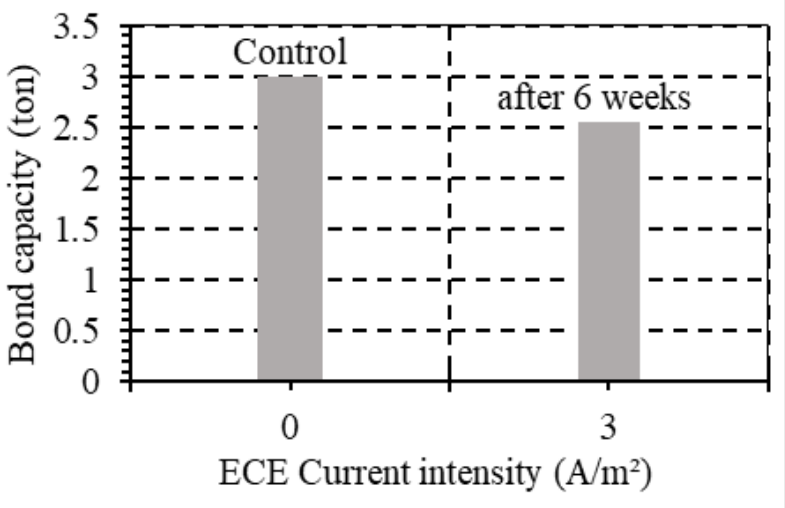

Fig. 14: Bond capacity before and after ECE

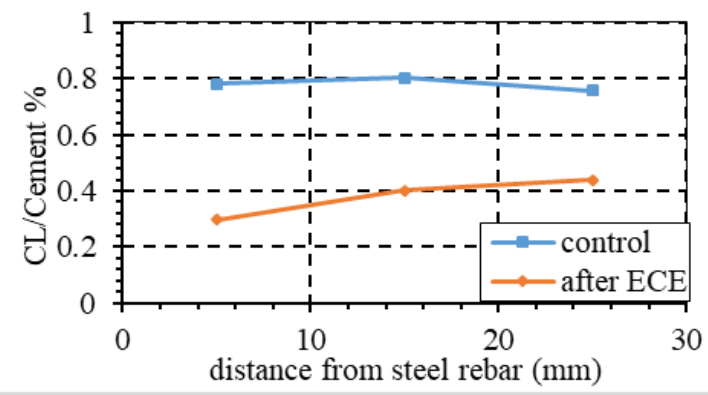

Fig. 15: Chloride content at different distances from steel bar after six weeks for mixture $\mathbf{2 . 5 \%}$ of pure chloride The results of chloride and pull-out test for all samples are shown in Appendix I and Appendix II. For each mixture there were three specimens and the graphs were drawn by the average of three specimens in each distance.

\section{CONCLUSION}

This study presents an experimental investigation carried out to evaluate the effectiveness of ECE by using locally available un-galvanized steel mesh anode with conductive cement paste on RC slab as a structural element. Based on the obtained test results, the following points can be easily concluded:

1. The obtained maximum efficiency of ECE process was at a location (on the RC slab) just above the steel rebar.

2. Effectiveness of ECE at any location of the RC slab depends on the distance between this location and the nearest steel rebar. The closer to the steel rebar, the more efficient of the ECE process.

3. There is no remarkable reduction in bond strength or compressive strength after applying ECE for 6 weeks duration and $3 \mathrm{~A} / \mathrm{m}^{2}$ current intensity.

4. Efficiency of ECE increased by increasing the initial chloride content of concrete. The measured efficiencies of ECE for different initial chloride contents were: $75 \%$ for $2.5 \%$ initial chloride content, $62 \%$ for $0.8 \%$ initial chloride content and $58 \%$ for $0.4 \%$ initial chloride content.

Published By:

Blue Eyes Intelligence Engineering \& Sciences Publication

(C) Copyright: All rights reserved. 


\section{APPENDIX}

Appendix I: Chloride content/Cement content \% for all samples at different distances from steel rebar

\begin{tabular}{|c|c|c|c|}
\hline \multirow{2}{*}{ Sample } & \multicolumn{3}{|c|}{ distance from steel rebar } \\
\cline { 2 - 4 } & $10 \mathrm{~mm}$ & $20 \mathrm{~mm}$ & $30 \mathrm{~mm}$ \\
\cline { 2 - 4 } M1C0D0* & \%Cl/ Cement & \%Cl/Cement & \%Cl/Cement \\
\hline M1S1C3D6** & 0.53 & 2.54 & 2.76 \\
\hline M1S2C3D6 & 0.52 & 0.85 & 0.78 \\
\hline M1S3C3D6 & 0.49 & 0.71 & 0.64 \\
\hline M2C0D0 & 0.4 & 0.73 & 0.63 \\
\hline M2S1C3D6 & 0.2 & 0.44 & 0.43 \\
\hline M2S2C3D6 & 0.22 & 0.26 & 0.26 \\
\hline M2S3C3D6 & 0.24 & 0.31 & 0.3 \\
\hline M3C0D0 & 0.78 & 0.33 & 0.29 \\
\hline M3S1C3D6 & 0.22 & 0.8 & 0.75 \\
\hline M3S2C3D6 & 0.38 & 0.38 & 0.45 \\
\hline M3S3C3D6 & 0.29 & 0.4 & 0.42 \\
\hline
\end{tabular}

(M1: first mixture, M2: Second mixture, M3: Third mixture)

Where $\mathrm{S}$ is the sample number, $\mathrm{C}$ is the current intensity of ECE, D is the duration of ECE treatment.

* Control sample for first mixture.

** Sample 1 with current intensity $3 \mathrm{~A} / \mathrm{m}^{2}$ and duration of ECE treatment six weeks.

Appendix II: Bond strength for all sa
\begin{tabular}{|c|c|} 
Sample & $\begin{array}{c}\text { Bond strength } \\
\text { (ton) }\end{array}$ \\
\hline M2C0D0 & 3 \\
\hline M2S1C3D6 & 2.8 \\
\hline M2S2C3D6 & 2.9 \\
\hline M2S3C3D6 & 2.8 \\
\hline M3C0D0 & 3 \\
\hline M3S1C3D6 & 2.5 \\
\hline M3S2C3D6 & 2.6 \\
\hline M3S3C3D6 & 2.6 \\
\hline
\end{tabular}

\section{REFERENCE}

1. M. Raupach and P. Schieß1, "Macrocell sensor systems for monitoring of the corrosion risk of the reinforcement in concrete structures," NDT E Int., vol. 34, no. 6, pp. 435-442, 2001, doi: 10.1016/S0963-8695(01)00011-1.

2. G. J. Al-Sulaimani, M. Kaleemullah, I. A. Basunbul, and Rasheeduzzafar, "Influence of corrosion and cracking on bond behavior and strength of reinforced concrete members," ACI Struct. J., vol. 87, no. 2, pp. 220-231, 1990.

3. G. K. Glass, B. Reddy, and N. R. Buenfeld, "The participation of bound chloride in passive film breakdown on steel in concrete," Corros. Sci., vol. 42, no. 11, pp. 2013-2021, 2000, doi: 10.1016/S0010-938X(00)00040-8.

4. J. Carmona, P. Garcés, and M. A. Climent, "Efficiency of a conductive cement-based anodic system for the application of cathodic protection , cathodic prevention and electrochemical chloride extraction to control corrosion in reinforced concrete structures," Corros. Sci., vol. 96, pp. 102-111, 2015, doi: 10.1016/j.corsci.2015.04.012.

5. P. Romano, P. S. D. Brito, and L. Rodrigues, "Monitoring of the degradation of concrete structures in environments containing chloride ions," Constr. Build. Mater., vol. 47, pp. 827-832, 2013, doi: 10.1016/j.conbuildmat.2013.05.042.

6. M. H. F. Medeiros, A. Gobbi, G. C. Réus, and P. Helene, "Reinforced concrete in marine environment : Effect of wetting and drying cycles , height and positioning in relation to the sea shore," Constr. Build. Mater., vol. 44, pp. 452-457, 2013, doi: 10.1016/j.conbuildmat.2013.02.078.

7. X. Shi, N. Xie, K. Fortune, and J. Gong, "Durability of steel reinforced concrete in chloride environments: An overview," Constr. Build. Mater., vol. 30, pp. 125-138, 2012, doi: 10.1016/j.conbuildmat.2011.12.038.
8. A. Abdelmonem, M. S. El-Feky, E.-S. A. R. Nasr, and M. Kohail, "Performance of high strength concrete containing recycled rubber," Constr. Build. Mater., vol. 227, 2019, doi: 10.1016/j.conbuildmat.2019.08.041.

9. M. Abdel Wahab, I. Abdel Latif, M. Kohail, and A. Almasry, "The use of Wollastonite to enhance the mechanical properties of mortar mixes," Constr. Build. Mater., vol. 152, pp. 304-309, 2017, doi: 10.1016/j.conbuildmat.2017.07.005.

10. M. S. El-Feky, A. M. El-Tair, M. Kohail, and M. I. Serag, "Nano-fibrillated cellulose as a green alternative to carbon nanotubes in nano reinforced cement composites," Int. J. Innov. Technol. Explor. Eng., vol. 8, no. 12, pp. 484-491, 2019, doi: 10.35940/ijitee.L3377.1081219.

11. N. Hani, O. Nawawy, K. S. Ragab, and M. Kohail, "The effect of different water/binder ratio and nano-silica dosage on the fresh and hardened properties of self-compacting concrete," Constr. Build. Mater., vol. 165, pp. 504-513, 2018, doi 10.1016/j.conbuildmat.2018.01.045.

12. N. Ghazaly, A. Rashad, M. Kohail, and O. Nawawy, "Evaluation of bond strength between steel rebars and concrete for heat-damaged and repaired beam-end specimens," Eng. Struct., vol. 175, pp. 661-668, 2018, doi: 10.1016/j.engstruct.2018.08.056.

13. A. Shamseldein, H. Elshafie, A. Rashad, and M. Kohail, “Assessment and restoration of bond strength of heat-damaged reinforced concrete elements," Constr. Build. Mater., vol. 169, pp. 425-435, 2018, doi: 10.1016/j.conbuildmat.2018.03.008.

14. O. M. Bakr, H. M. Elkady, E. A. R. Nasr, and M. Kohail, "Assessment of mechanical and fire resistance for hybrid nano-clay and steel fibres concrete at different curing ages," J. Struct. Fire Eng., 2019, doi: 10.1108/JSFE-06-2019-0024.

15. G. E. Abdelaziz, A. M. K. Abdelalim, and Y. A. Fawzy, "Cement and Concrete Research Evaluation of the short and long-term ef fi ciencies of electro-chemical chloride extraction," Cem. Concr. Res., vol. 39, no. 8, pp. 727-732, 2009, doi: 10.1016/j.cemconres.2009.05.015.

16. J. C. Orellan, G. Escadeillas, and G. Arliguie, "Electrochemical chloride extraction : efficiency and side effects," vol. 34, pp. 227-234, 2004, doi: 10.1016/j.cemconres.2003.07.001.

17. B. Elsener, M. Molina, and H. Böhni, "The electrochemical removal of chlorides from reinforced concrete," Corros. Sci., vol. 35, no. 5-8, 1993, doi: 10.1016/0010-938X(93)90385-T.

18. V. Saraswathy and H. Song, "Improving the durability of concrete by using inhibitors," vol. 42, pp. 464-472, 2007, doi: 10.1016/j.buildenv.2005.08.003.

19. R. B. Polder, "Electrochemical chloride removal from concrete prisms containing chloride penetrated from sea water," Constr. Build. Mater., vol. 10, no. 1 SPEC. IS, pp. 83-88, 1996, doi: 10.1016/0950-0618(95)00062-3.

20. C. Xu et al., "Organic corrosion inhibitor of triethylenetetramine into chloride contamination concrete by eletro-injection method," Constr. Build. Mater., vol. 115, pp. 602-617, 2016, doi: 10.1016/j.conbuildmat.2016.04.076.

21. V. Saraswathy and S. P. Karthick, "Effect of ecofriendly sealing coat against corrosion protection of steel rebars in concrete," no. August, 2014, doi: 10.1179/1743278213Y.0000000133.

22. L. Bertolini, F. Bolzoni, P. Pedeferri, L. Lazzari, and T. Pastore, "Cathodic protection and cathodic prevention in concrete: Principles and applications," J. Appl. Electrochem., vol. 28, no. 12, pp. 1321-1331, 1998, doi: 10.1023/A:1003404428827.

23. "Egyptian Code of Practice: ECP 203. Design and Construction for Reinforced Concrete Structures, Ministry of Building Construction, Research Center for Housing, Building and Physical Planning." Cairo, Egypt, 2017.

24. R. Elgebaley, Y. Elshazly, and M. Elsalamawy, "Role of cement type on performance change of reinforcing steel due to chloride extraction,' Constr. Build. Mater., vol. 208, pp. 444-453, 2019, doi: 10.1016/j.conbuildmat.2019.03.022.

25. V. Saraswathy, H. S. Lee, S. Karthick, and S. J. Kwon, "Extraction of chloride from chloride contaminated concrete through electrochemical method using different anodes," Constr. Build. Mater., vol. 158, pp. 549-562, 2018, doi: 10.1016/j.conbuildmat.2017.10.052.

\section{Published By:}

Blue Eyes Intelligence Engineering

\& Sciences Publication

(C) Copyright: All rights reserved. 
26. H. Lin, Y. Li, and Y. Li, "A study on the deterioration of interfacial bonding properties of chloride-contaminated reinforced concrete after electrochemical chloride extraction treatment," Constr. Build. Mater., vol. 197, pp. 228-240, 2019, doi 10.1016/j.conbuildmat.2018.11.196.

27. Y. Li, X. Liu, M. Wu, and W. Bai, "Research of electrochemical chloride extraction and reinforcement of concrete column using MPC-bonded carbon fiber reinforced plastic sheet \& mesh," Constr. Build. Mater., vol. 153, pp. 436-444, 2017, doi: 10.1016/j.conbuildmat.2017.07.131.

28. B. Ma et al., "Effect of TIPA on Chloride Immobilization in Cement-Fly Ash Paste,” Adv. Mater. Sci. Eng., vol. 2018, 2018, doi: 10.1155/2018/4179421.

29. S. T. Method, "Standard Test Method for Half-Cell Potentials of Uncoated Reinforcing Steel in,” vol. 03, no. Reapproved, 1999.

30. ASTM C1585-13, "Standard Test Method for Measurement of Rate of Absorption of Water by Hydraulic Cement Concretes," ASTM Int., vol. 41, no. 147, pp. 1-6, 2013, doi: 10.1520/C1585-13.2.

31. "Laboratory test manual for concrete materials, Annex III." 2002.

\section{AUTHORS PROFILE}

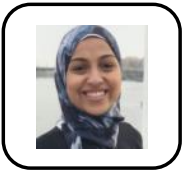

Eng. Nourhan El-sayed is a demonstrator at the Structural Engineering Department, Faculty of Engineering, Ain Shams University (ASU). She teaches properties and strength of materials for engineering students in Ain Shams University. Nourhan is a master student at properties and strength of materials section, Structural Engineering Department, ASU. Her research interests focuses on the protection against corrosion of steel reinforcement, sustainability, repair and strengthening of RC structures and applications of Geopolymer materials in the structural field. She is a member of material research center (MRC). She is Quality control engineer, Engineering Consultation center, Ain Shames University. She supervises material tests in lab, compression, tension, bending and shear tests and prepares technical reports on these tests.

In addition to that, she supervises on conducting tests on site such as core test, ultrasonic test, schmedit hammer and calibration for machines.

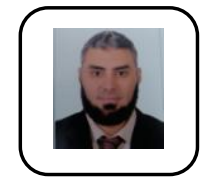

Dr. Mohamed Kohail is an Associate Professor, Structural Engineering Department, Faculty of Engineering, Ain Shams University, Egypt. He is a member of material research center (MRC). Dr. Kohail is specialized in construction materials, sustainability, and Nano-technology. He published more than ten international publications in these areas. He is also an editor for Ain Shams Engineering Journal (ASEJ under Elsevier), he also reviews many papers for high ranked journals and conferences. Dr. Kohail is an active member of interdisciplinary research team which includes member from National Research Centre, Cairo University, Faculty of Science, and German University in Cairo. Dr. Kohail is also the post graduated coordinator. Recently, Dr. Kohail has promoted to be vice director of i-Hub (Innovation Hub). i-Hub is an organization aims to link the gap between industry and academic research which supports students, researchers, and startups all over Egypt.

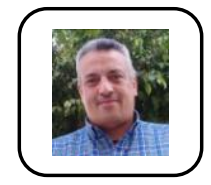

Dr. Mohamed Abdel Moaty Khalaf was graduated from Structural Engineering department, Faculty of Engineering, Ain Shams University, Cairo, Egypt in June1990. He got his M.Sc. from the same department in 1993 in the field of CATHODIC PROTECTION OF STEEL REINFORCEMENT. He got his Ph.D from Drexel University, PA, USA in 2001 in the field of FATIGUE BEHAVIOR OF GFRP PULTRUDED BEAMS. Now he is a Professor of properties and strength of materials in the same department. His scientific research interest is in the fields of protection against corrosion of steel reinforcement, repair and strengthening of RC structures and applications of FRP materials in the structural field In addition to that, He supervised many Master and Doctoral thesis in properties and strength of materials. 